\title{
INTERNET BANKING AWARENESS AND PREFERENCES AMONG YOUNG PEOPLE IN POLAND
}

\begin{abstract}
Internet banking is a fast growing segment of banking services worldwide, expanding in direct proportion to the development of local internet network. In Poland, the first online banking services appeared 16 years ago and were introduced as a part of selected banks' offer. Since then systematic development of the segment has been observed in terms of a number of signed contracts and active clients. At the beginning of 2014 Polish banks signed about 22 million contracts for the provision of internet banking services and the estimated share of active clients was approximately $56 \%$.

The strongest interest in this kind of banking services in Poland was paid by young people under 35 years old. This apparently results from them using the internet on regular, daily basis (approximately 90\%). Thus, the youths under 25 were chosen as the future target banking segment for the research on electronic banking preferences.

The article presents selected findings of the survey on awareness and preferences among young people in the field of internet banking. The research allowed us to estimate the level of public interest in internet banking services as well as indicate factors influencing the choice of a particular bank and internet banking services. The research was targeted to future bank clients, currently in the segment of university students.
\end{abstract}

Keywords: e-banking, i-banking, online banking, banking service, transactional websites, opinion poll.

\section{INTRODUCTION}

The development of internet technologies along with increasing accessibility ofinternet services contributed vastly to changes observedin the worldwide economy including banking sector. Electronic banking has become standard nowadays and is considered one of the primary determinants of the information society. Currently, over $40 \%$ of the Europeans use electronic banking services and the share grows each and every year. Scandinavian countries are the market leaders as the number of active users exceeds $80 \%$ in those states. The interest in e-banking services is a bit less intense in the European corecountries, where the number of users runs at about $50 \%$. The third place in the rankbelongs tothe countries of Central and Eastern Europe preceding the countries of the Iberian and Apennine Peninsulas. In Poland, in accordance with the Research Report BS/75/2013 on Internet use in 2013 by Public Opinion Research Centre, the number of

\footnotetext{
${ }^{1}$ Dr inż. Mirosław Sołtysiak, Zakład Finansów i Bankowości, Wydział Zarządzania, Politechnika Rzeszowska, al. Powstańców Warszawy 8, 35-959 Rzeszów, tel. 17 8651915, corresponding author: e-mail: miroslaw@ @rz.edu.pl

${ }^{2}$ Mgr Magdalena D. Suraj, Zakład Finansów i Bankowości, Wydział Zarządzania, Politechnika Rzeszowska, al. Powstańców Warszawy 8, 35-959 Rzeszów, tel. 17 8651915, e-mail: madeline@prz.edu.pl
} 
adult Poles activelyusinginternetincreases each and every year. Thus, in 2013,6 of 10 adult Poles used internet at least once a week. As far as age criterionis concernedit is the young people who are most willing to use internet (in the group of 18-24 years - 93\% of population, 25-34 years - 88\%). When it comes to education level criterion, $92 \%$ of the highly educated people use internet on regular basis, whereas in the group of people with secondary education it is $73 \%$. This knowledge seems to be of key significance for the development of internet banking in Poland. Only now $36 \%$ of respondents admit using online banking services at least once a month. Bearing in mind the number of internet users in the youngestage groups one may expect the growing trend to continue in the coming years.

\section{INTERNET BANKING}

Internet banking is understood as a type of electronic banking where customer contacts their bank via internet. Internet banking services are usually offered by virtual banks but also by traditional banks having electronicbranches (branches providing services via internet). Thus, all banking services are provided solely in virtual space and internet is used as the main distribution channel for banking services.

Wells Fargo NetBank, Nordea Bank and Bank of America are regarded the pioneers of internet banking. The first bank to have offered their customers banking services via internet was La Jolla Bank FSB. The bank was established in December 1995 in California, USA.Regarding Europe the first internet banks appeared in 1996 in twoScandinavian countries:SEB in Sweden and Merita Nordbankenin Finland. The first Polish internet bank was called mBank and founded in November 2000. However, there had been some Internet services offered before by traditional banks. Just to mention Universal Bank Commercial S.A. in Łódź, where the very first internet services were provided to Polish clients. The bank's first electronic branch was opened on October 14, 1998. Moreover, the first cooperative bank to have launched internet services was Podkarpacki Cooperative Bank of Sanok (September 2000).

\section{MARKET OF INTERNET BANKING IN POLAND}

The number of individual bank customersusing banking services viainternet in Poland is steadily growing. According to the reports published by the Polish BankAssociation (PBA)thenumber of signed contracts for internet banking services amounted to $16.2 \mathrm{~m}$ in $2010,17.8 \mathrm{~m}$ in $2011,20.8 \mathrm{~m}$ in $2012,21.8 \mathrm{~m}$ in 2013.

It is quite interesting that the number of active online banking users (Fig. 1) grows in proportion to the increase in the number of accounts and remains ona similar level of $56 \%$. It should be noted, however, that recently the number ofcustomers intentionally signingthe online services agreement has been growing. In general, they intend to benefit from the services actively, not just as supplement to the bank core services.

It is reported that banks are reluctant to reveal data concerning the active users of online banking services. According to the PRNews.pl Report the largest number of active users had PKO BP SA $(2.821 \mathrm{~m}$ in $2012,3.005 \mathrm{~m}$ in 2013$)$ followed by BZ WBK $(1.541 \mathrm{~m}$ in 2012, 1.554m in 2013), Pekao SA (1.148m in 2012, 1.261m in 2013) and ING Bank Śląski (1.073 million in 2012, 1,192 million in 2013). 
One shall remember that the largest Polish internet bank - mBank - having approximately $3.251 \mathrm{~m}$ online banking customers in 2013 refuses to inform about the exact number of active users.

Fig. 1.Number of active online banking users in millions

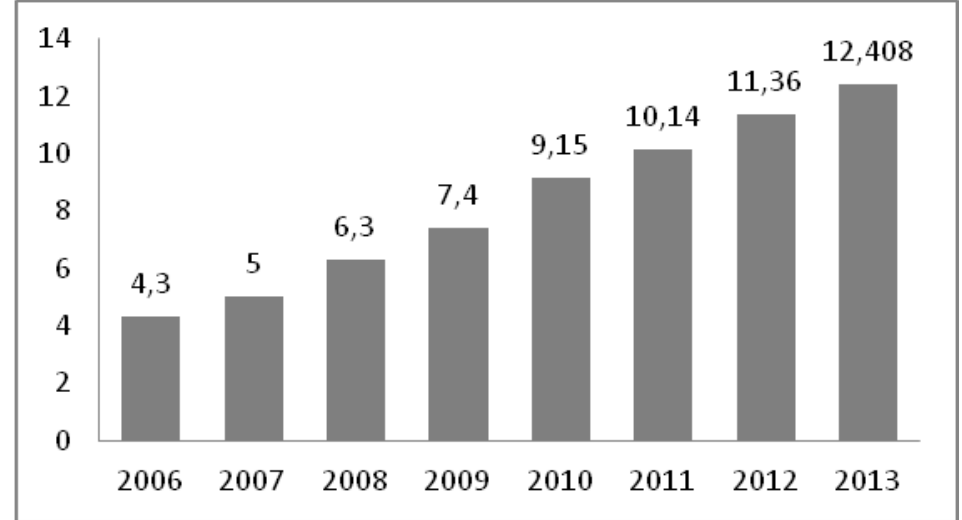

(Source: Own elaboration based on PBA data)

\section{INTERNET BANKING IN POLAND - AWARENESS AND PREFERENCES AMONG YOUNG PEOPLE}

The fundamental objective of the survey was to determine the awareness and preferences of young people in the field of online banking. The research was intended to estimate their interest in the services of online banking, identify factors influencing the choice of a particular bank as well as showthe most popular Internet banking services.

Fig. 2.Number of respondents using banking services

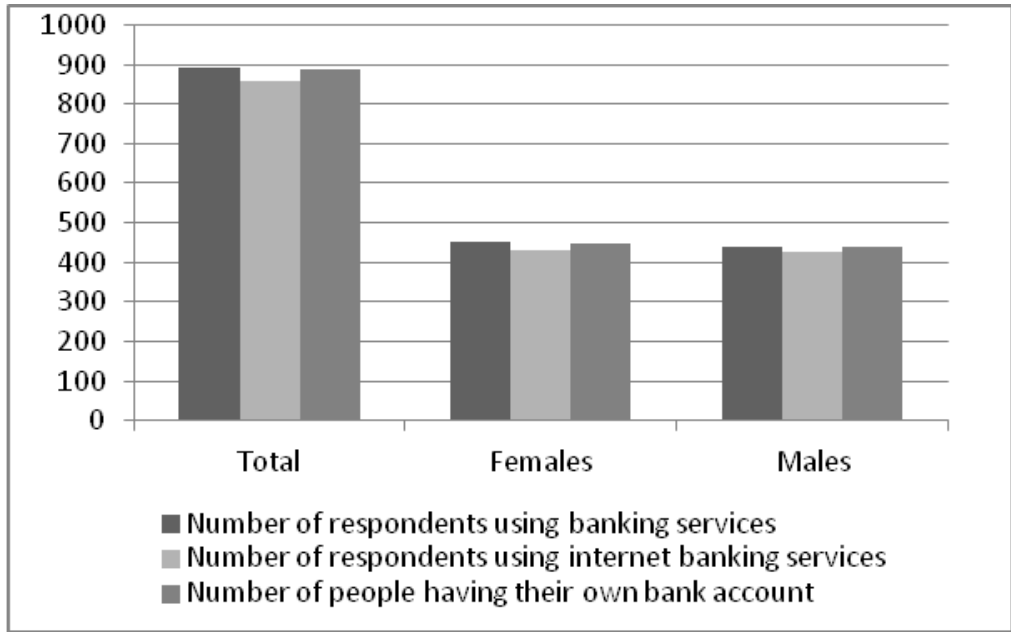

(Source: Own elaboration) 
The primary research was conducted on a group of 897 respondents aged 20-25 studying at Subcarpathian universities. The research samplecomprised 453 women and 444 men. The sample choice was dictated simply by the fact that the percentage of internet users in this age group is about $93 \%$. What is more, young people, as potential clients, become the target group for many banks.

In this article only selected findings of the research are elaborated due to editorial constraints.

In the first part of the survey the respondents answered general questions concerning using banking services. Interestingly enough $95.65 \%$ of them admit using online banking services and simultaneously $98.77 \%$ have their own bank account compared to $99.2 \%$ using banking services in general (Fig. 2).

Fig. 3.Popularity of banks among young people - criterion of bank type

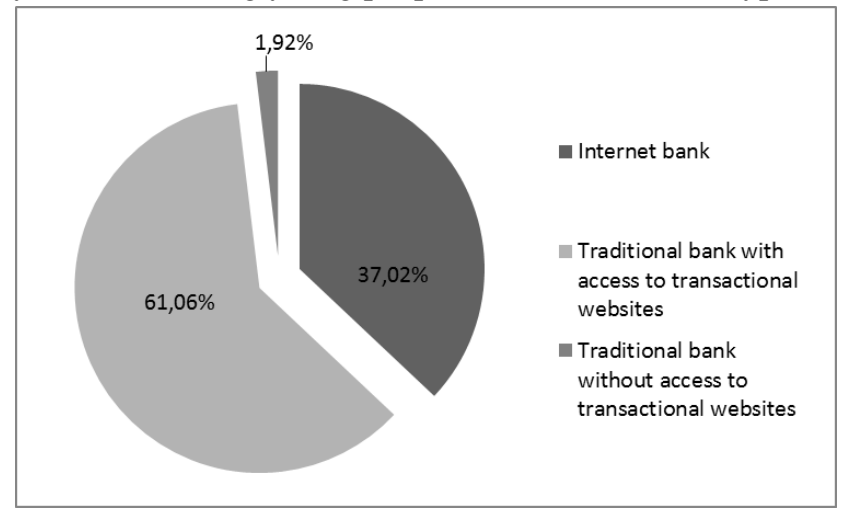

(Source: Own elaboration)

Another question referred to the type of bank where the respondents hadtheir bank account established (Fig. 3). It turns out that young customers particularly appreciate the opportunity to performtransactionsviainternet. According to the survey over $98 \%$ of young people hadtheir accounts in banks providingso called transactional websites, where basic online banking services are available. However, only $37 \%$ of the respondents set up their bank accounts in pure play internet banks. This kind of banking was popular more among men $(41 \%)$ than women $(33 \%)$.

The conducted research has proved that there is still a significant group of young customers enjoying direct relation with their bank. Banks delivering transactional websites to their clients were popular among $61 \%$ of the respondents. Balances with banks and traditional Internet service providers had $61 \%$ of respondents. This banktype is more often chosen by women $(64.3 \%)$ than men $(57.6 \%)$. In addition, mere $1.92 \%$ of the survey respondents admitted having an account in a bank with no transactional websites.It is interesting to note that most of such accounts were opened in small cooperative banks and the vast majority of their holders (over 70\%) were planning to open another account with the access to virtual transactions.

Another issue addressed in the study concerned the factors affectingthe choice of a bank(Figure 4). Regardless of the gender, the possibility to use banking services viathe 
internet was the most desirable among the respondents. This optionwas chosen by $88 \%$ of males and $80 \%$ offemales.

Fig. 4.Determinants of bank selection choices

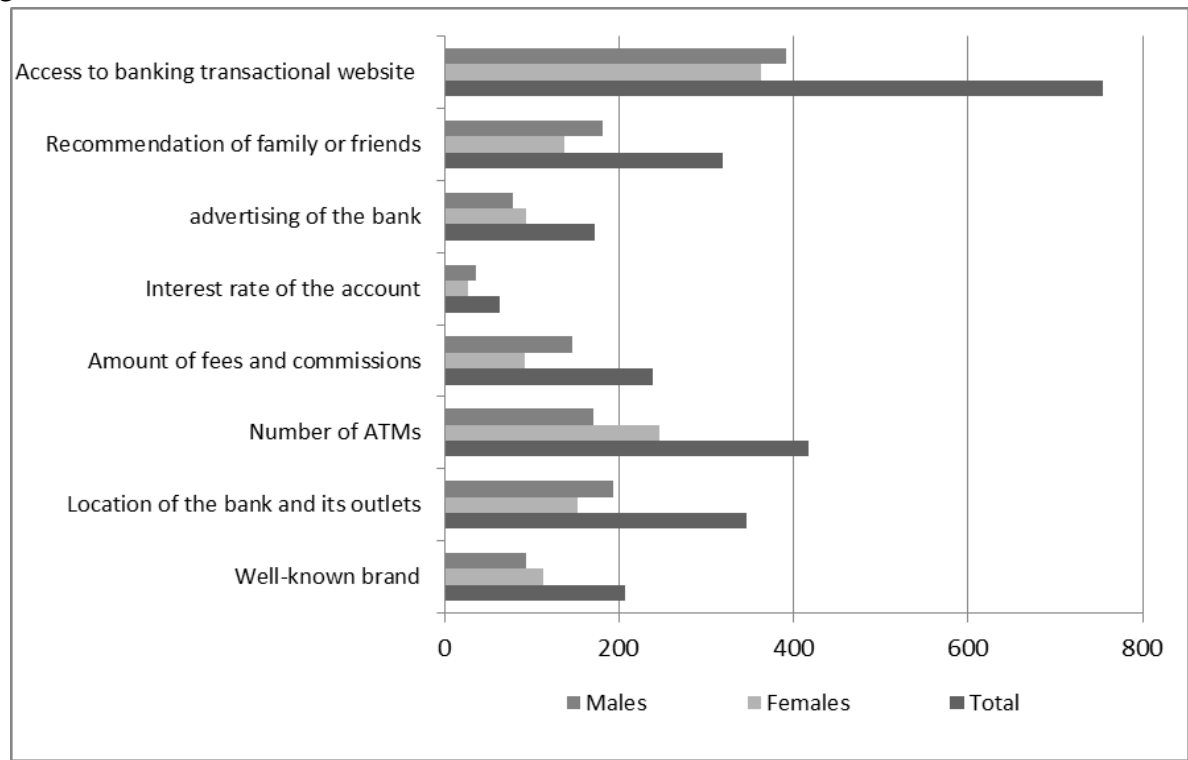

(Source: Own elaboration)

Another significant criterion seemed to be the number of ATMs available for use that option was indicated by $54.5 \%$ of women and $38.3 \%$ of men. Bank location and number of outlets were a little less important for the interviewees as only $33.7 \%$ of women and up to $43.5 \%$ of men selected that answer. The latterlooks quite interesting bearing in mindthe previous question and its results (usually ATMs in Poland are located in a branch premises). It can be interpreted that that for a large female group the possibility to withdraw cash directly from an ATM is more important than doing it by personal contact with the bank's employee. This is important information for banks in the context of the development of their long-term strategy. It can be vital for the banks as far as developing long-term strategies is concerned.

According to the survey immediate environment such as family or friends influences more the choice of a bank, than brands or advertising. Recommendations mattered for $30.5 \%$ of women, whereasin the case of a bank's brand it is $25 \%$, advertising $-20.7 \%$. In the male sample the percentage shares were respectively $40.7 \%, 21 \%, 17.7 \%$.

The last group of factors related to the bank choice by young people in Poland were concerned with financial aspects. The amount of fee and commission were given consideration by every fifth woman and every third man participating in the survey. Surprisingly the interest rates offered by the banks were less important as it was indicated in the questionnaire by mere $6 \%$ of females and $8 \%$ of males. The above can be explained 
by the life cycle stage of the survey respondents - they tend to be more consumptionoriented rather than accumulation-oriented.

Fig. 5.Acceptable monthly expenses related to the access to transactional websites

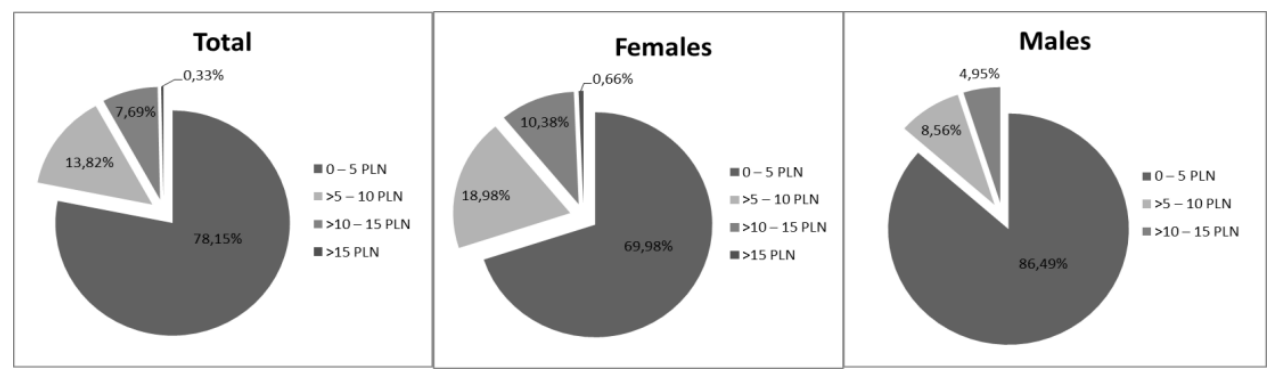

(Source: Own elaboration)

Further analysis of the research data allows the conclusion that Polish women in general are more likely to incur higher costs as far as keeping their virtual bank accountis concerned. Although the percentage share was very low $(0.66 \%)$ but still, some of the female respondents would agree on their account monthly expenses higher than 15 PLN.

Majority of the respondents chose the lowest level of expenses - up to 5 PLN monthly (86\% of men and $70 \%$ of women). The costs ranging from 5 PLN to 10 PLN were accepted by $19 \%$ of women and $8.5 \%$ of men (Fig. 5).

Fig. 6.Frequency of bank transactional websites use

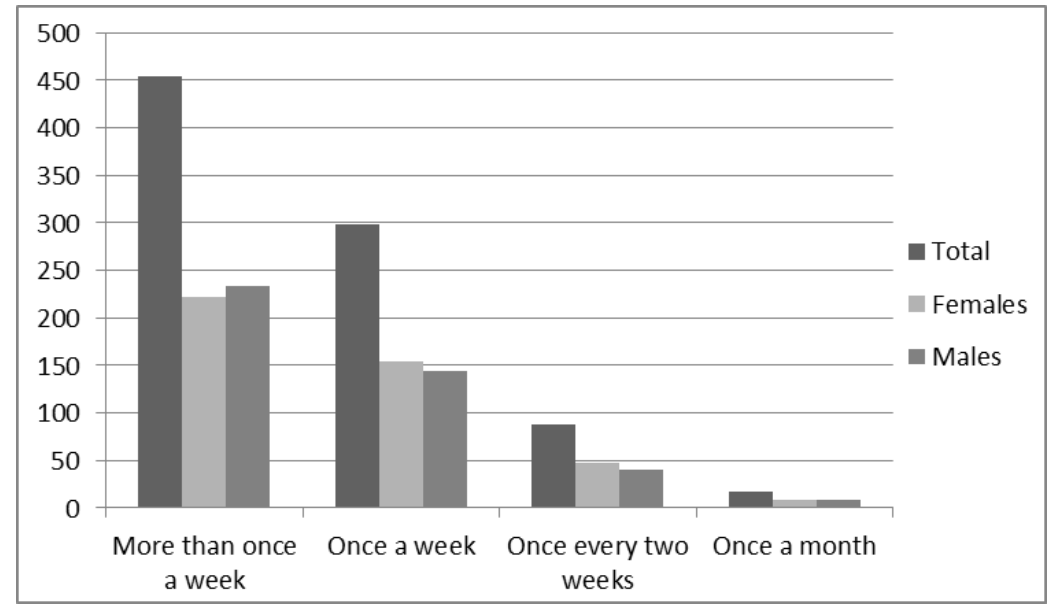

(Source: Own elaboration) 
Taking into consideration the frequency of banking services use viainternet one shall note that online services are very popular among the 20 - 25 year old people (Fig. 6). Over $53 \%$ of the respondents admitted usingsuch services more often than once a week and further $34.7 \%$ of them - at least once a week. The respondents usingtransactional websites only once a month comprised mere $2 \%$ of the research sample. The research outcome proves that banking services should be developed further in the online form, if addressed to young educated customers.

Fig. 7.Reasons of banking transactional websites use

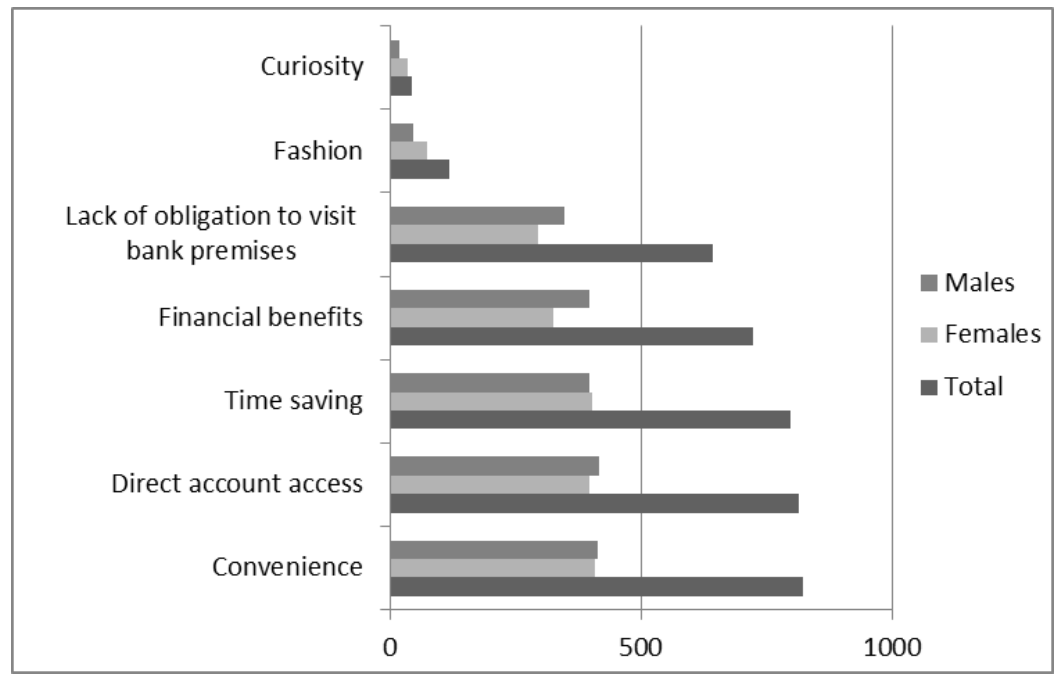

(Source: Own elaboration)

Convenience is the most significant factor influencing the use of transactional websites in the case of banking services (Fig. 7). It matters most for $96 \%$ of the respondents, respectively $94.7 \%$ of women and $97.2 \%$ men. Other factors indicated by the female respondents are as follows: time saving (93.05\%), direct account access $(91.9 \%)$ and financial benefits $(75.46 \%)$. However, the male respondents appreciated more the direct access to their account $(97.88 \%)$ and ranked the below factors as follows: convenience (97.2\%), financial benefits (93.19\%), time saving (92.96\%).

Typical online banking operations held by young Poles are checking the account balance $(98.72 \%)$ and the account records $(97.44 \%)$ according to the survey. Moreover, they pay their bills $(90.44 \%)$, transfer money $(88.34 \%)$ and top-up their mobile phones $(84.96 \%)$. It should be noted, however, that these services are more popular among men rather than women. In the case of the latter paying forshopping is more frequent $-61.8 \%$ of women pay for shopping online as compared to $49.5 \%$ of men (Figure 8). 
Additionally, $7.1 \%$ of the survey respondents useinternet to make banking deposits. And again, this service is more popular among men (11.5\%) than women $(2.77 \%)$.

Fig. 8.Typical online banking operations

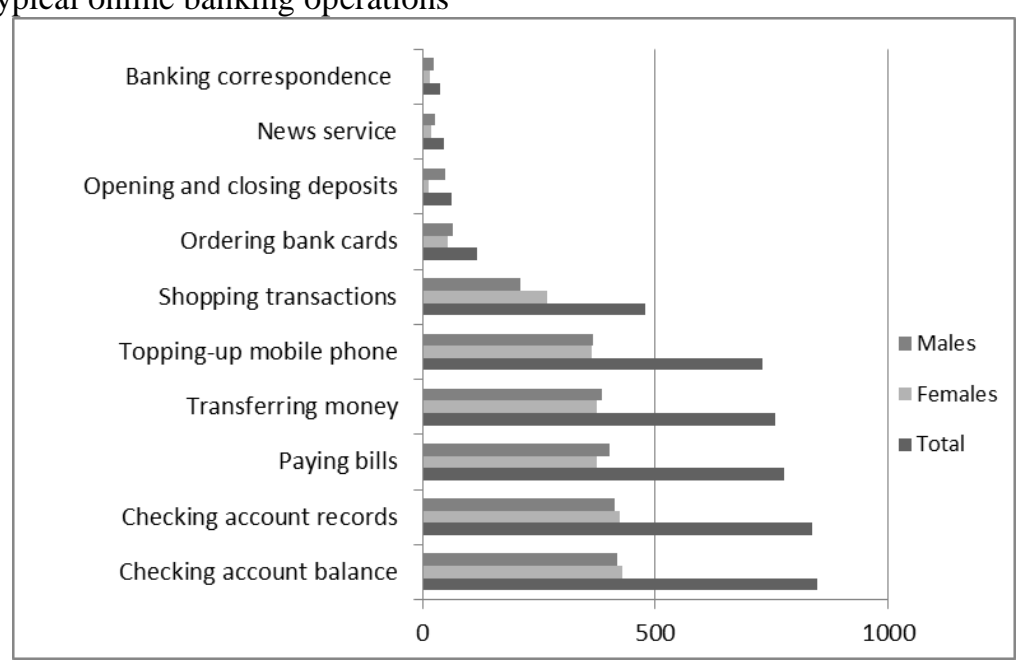

(Source: Own elaboration)

Fig. 9.Will online banking substitute real-play banking in the future?

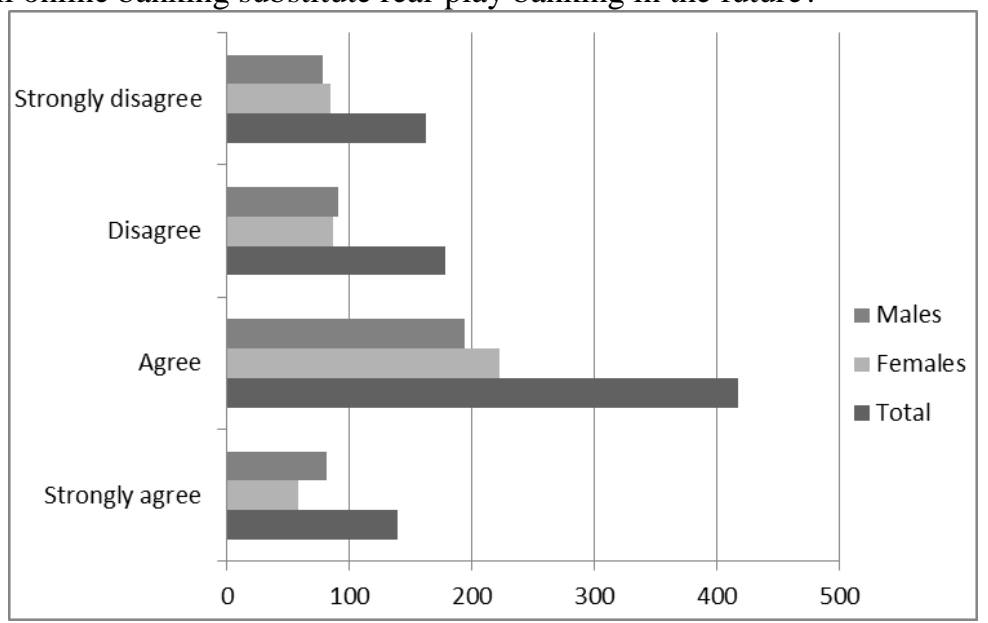

(Source: Own elaboration)

A natural consequence of the survey -the question about the future of mortar and brick banks may be asked. And it was askedto the young survey respondents. They seemed to be very certain about real-play banks' future - approximately six out of ten respondents predict traditional banks may be substituted by virtual banks $(15.5 \%$ of the respondents are quite sure about that and $46.49 \%$ of them admit such possibility). Mere $18.17 \%$ of the 
respondents strongly ruled out the possibility of traditional banks'liquidation in the future $(18.76 \%$ of women and $17.57 \%$ of men).

\section{CONCLUSION}

Despite the history of online banking being relatively short, especially if compared to long history of banking, it seems to play a significant rolethese days. It has already become an indispensable segment of modern banking and serves as competitive edge and market survival guarantee.

Online banking benefits from latest technological advances and allows most of the banks to become modern financial institutions, which can bring down operational costs as well as satisfy their clients' needs.

The survey's outcome proves undoubtedly that young generation representatives, these born up to 25 years ago, cannot imagine banking without online banking. Over of $60 \%$ of the respondents believe it may be the main means of communication between clients and their banks, and may also lead to complete elimination of traditional banks.

\section{REFERENCES}

[1] Komunikat Badań BS/75/2013 Internauci 2013. Centrum Badania Opinii Społecznej [online]. [2014-06-15]. http://www.cbos.pl/SPISKOM.POL/2013/K_075_13.PDF.

[2] Raport PRNews.pl: Rynek bankowości internetowej - I kw. 2014 [online]. [2014-06-15].http://prnews.pl/raporty/raport-prnewspl-rynek-bankowosciinternetowej-i-kw-2014-3143419.html.

[3] Raport PRNews.pl: Rynek bankowości internetowej - IV kw. 2013[online]. [2014-06-15]. http://prnews.pl/raporty/raport-prnewspl-rynek-bankowosciinternetowej-iv-kw-2013-3089193.html.

[4] Raport PRNews.pl: Rynek bankowości internetowej - I kw. 2013[online]. [2014-06-15]. http://prnews.pl/raporty/raport-prnewspl-rynek-bankowosciinternetowej-i-kw-2013-2787131.html.

[5] Sołtysiak M.,Raport $\mathrm{z}$ badań Bankowość internetowa - świadomość i preferencje młodych ludzi. Rzeszów 2014-typescript.

[6] Sołtysiak M., Wybrane zagadnienia bankowości pojęcia i ćwiczenia. Oficyna Wydawnicza Politechniki Rzeszowskiej, Rzeszów 2013.

[7] Sołtysiak M., Bankowość internetowa jako przykład innowacji na rynku usług bankowych.Zeszyty Naukowe Politechniki Rzeszowskiejvol. 250, Zarządzanie i Marketing vol. 14/ 2008, pp. $303-310$.

\section{BANKOWOŚĆ INTERNETOWA - ŚWIADOMOŚĆ I PREFERENCJE MLODYCH LUDZI}

Bankowość internetowa stanowi na całym świecie dynamicznie rozwijający się segment usług bankowych, który w różnych częściach świata rozwija się wprost proporcjonalnie do rozwoju lokalnych świeci internetowych. W Polsce pierwsze usługi bankowości internetowej pojawiły się w ofercie wybranych banków 16 lat temu. Od tego momentu notowany jest systematyczny rozwój tego segmentu usług bankowych charakteryzujący się wzrostem ilości podpisanych umów a przede wszystkim wzrostem liczby aktywnych 
klientów. Na początku 2014 roku polskie banki miały podpisanych ok. 22 miliony umów na świadczenie usług bankowości internetowej a szacowany udział aktywnych klientów wynosił ok. $56 \%$.

Największe zainteresowanie tego rodzaju usługami bankowymi na polskim rynku bankowych wykazywały osoby młode, które nie ukończyły jeszcze 35 roku życia. Związane jest to $\mathrm{z}$ faktem, że $\mathrm{w}$ tej właśnie grupie wiekowej najwięcej osób korzysta na co dzień z Internetu (około 90\%). Dlatego do badań dotyczących preferencji związanych z bankowością elektroniczną zostały wybrane jako przyszłościowy segment docelowy banków osoby młode do 25 roku życia.

W artykule przedstawiono wybrane wyniki badań dotyczących stanu świadomości i preferencji młodych ludzi w zakresie bankowości internetowej. Przeprowadzone badania pozwoliły na oszacowanie poziomu zainteresowania usługami bankowości internetowej, wskazanie czynników wpływających na wybór określonego banku oraz usług bankowości internetowej cieszących się największym zainteresowaniem klientów bankowych zaliczanych do segmentu dzisiejszych studentów wyższych uczelni.

Slowa kluczowe: e-banking, i-banking, usługa bankowa, postrzeganie, studenci.

DOI:10.7862/rz.2014.hss.48

Przesłano do redakcji: czerwiec 2014

Przyjęto do druku: październik 2014 